\title{
Simvastatin attenuates ventilator-induced lung injury in mice
} Holger C Müller ${ }^{1 *}$, Katharina Hellwig ${ }^{1}$, Simone Rosseau ${ }^{1}$, Thomas Tschernig ${ }^{2}$, Andreas Schmiedl ${ }^{3}$, Birgitt Gutbier ${ }^{1}$,
Bernd Schmeck ${ }^{1,4}$, Stefan Hippenstiel ${ }^{1}$, Harm Peters ${ }^{5}$, Lars Morawietz ${ }^{6}$, Norbert Suttorp ${ }^{1}$, Martin Witzenrath ${ }^{1}$

\begin{abstract}
Introduction: Mechanical ventilation (MV) is a life saving intervention in acute respiratory failure without alternative. However, particularly in pre-injured lungs, even protective ventilation strategies may evoke ventilatorinduced lung injury (VILI), which is characterized by pulmonary inflammation and vascular leakage. Adjuvant pharmacologic strategies in addition to lung protective ventilation to attenuate VILI are lacking. Simvastatin exhibited anti-inflammatory and endothelial barrier stabilizing properties in vitro and in vivo.

Methods: Mice were ventilated (12 ml/kg; six hours) and subjected to simvastatin ( $20 \mathrm{mg} / \mathrm{kg}$ ) or sham treatment. Pulmonary microvascular leakage, oxygenation, pulmonary and systemic neutrophil and monocyte counts and cytokine release in lung and blood plasma were assessed. Further, lung tissue was analyzed by electron microscopy.

Results: Mechanical ventilation induced VILI, displayed by increased pulmonary microvascular leakage and endothelial injury, pulmonary recruitment of neutrophils and $\mathrm{Gr}-1^{\text {high }}$ monocytes, and by liberation of inflammatory cytokines in the lungs. Further, VILI associated systemic inflammation characterized by blood leukocytosis and elevated plasma cytokines was observed. Simvastatin treatment limited pulmonary endothelial injury, attenuated pulmonary hyperpermeability, prevented the recruitment of leukocytes to the lung, reduced pulmonary cytokine levels and improved oxygenation in mechanically ventilated mice.
\end{abstract}

Conclusions: High-dose simvastatin attenuated VILI in mice by reducing MV-induced pulmonary inflammation and hyperpermeability.

\section{Introduction}

In acute respiratory failure, mechanical ventilation (MV) is a life saving treatment without alternatives, and MV is also employed following surgery or trauma. One third of all patients in intensive care units worldwide receive MV [1]. However, particularly in preinjured lungs even minimal MV-associated physical stress may evoke ventilator-induced lung injury (VILI), an important undesirable effect of respirator therapy [2,3]. VILI is characterized by a pulmonary inflammatory response with the liberation of cytokines, recruitment of leukocytes to the lung and increased lung permeability, consecutively resulting in lung edema, surfactant dysfunction, impaired lung compliance and deterioration

\footnotetext{
* Correspondence: holger.mueller@charite.de

'Department of Infectious Diseases and Pulmonary Medicine, Charité -

Universitätsmedizin Berlin, Charitéplatz 1, 10117 Berlin, Germany

Full list of author information is available at the end of the article
}

of pulmonary gas exchange [4]. Clinical studies of Amato et al. and the ARDS Network revealed that minimization of MV-induced physical stress by reduction of tidal volumes to $6 \mathrm{ml} / \mathrm{kg}$ significantly improved the clinical outcome of mechanically ventilated patients $[5,6]$. However, even low tidal volume ventilation of healthy lungs causes lung injury [7], and particularly preinjured lungs are sensitive to the development of VILI even in the setting of lung-protective ventilation [2,3]. As the necessity to guarantee sufficient gas exchange limits a further substantial reduction of tidal volumes, new adjuvant pharmacological therapies in addition to lung-protective ventilation are needed to prevent VILI.

Simvastatin, a 3-hydroxy-3-methylglutaryl coenzyme A (HMG-CoA) reductase inhibitor belonging to the group of statins may be a promising drug candidate for adjuvant pharmacotherapy in MV. Besides well-known lipid lowering properties, simvastatin exhibits pleiotropic 
effects that attenuated acute lung injury (ALI), including reduction of pulmonary microvascular leakage, limitation of pulmonary leukocyte infiltration, and attenuation of pulmonary and systemic hyperinflammation in different experimental settings [8-11]. Moreover, statins may alter inflammatory responses in humans. Healthy volunteers subjected to lipopolysacharide (LPS) inhalation developed lung inflammation, which was attenuated by simvastatin treatment [12]. Further, statin treatment was associated with improved survival in sepsis and severe community acquired pneumonia [13-16].

Pulmonary and systemic hyperinflammation, leukocyte recruitment to the lungs, and the development of pulmonary microvascular leakage are crucial components of VILI [4,17]. We thus hypothesized that simvastatin may reduce VILI and may be a promising adjuvant pharmacologic strategy to limit VILI in addition to lung protective ventilation.

In the current study, anesthetized mice were subjected to mechanical ventilation for six hours. Simvastatin treatment markedly attenuated ventilator-induced pulmonary microvascular permeability and endothelial injury, recruitment of neutrophils and $\mathrm{Gr}-1^{\text {high }}$ monocytes, as well as proinflammatory cytokine levels in the lung, and improved oxygenation considerably.

\section{Materials and methods \\ Mice}

Female C57BL/6 mice (11 to 15 weeks, 20 to $22 \mathrm{~g}$ ) (Charles River, Sulzfeld, Germany) were employed. Procedures were approved by institutional and governmental authorities.

\section{Mechanical ventilation}

Mice were anesthetized by intraperitoneal injections of Fentanyl $(0.075 \mathrm{mg} / \mathrm{kg})$, Midazolam $(1.5 \mathrm{mg} / \mathrm{kg})$ and Medetomedin $(0.75 \mathrm{mg} / \mathrm{kg})$. Repetitive applications of Fentanyl $(0.016 \mathrm{mg} / \mathrm{kg})$, Midazolam $(0.33 \mathrm{mg} / \mathrm{kg})$ and Medetomedin $(0.16 \mathrm{mg} / \mathrm{kg})$ were done via an intraperitoneal catheter when required to guarantee adequate anaesthesia over the whole experiment. Body-temperature was maintained at $37^{\circ} \mathrm{C}$ by a heating pad. After tracheotomy and intubation, mice were ventilated (MiniVent, Hugo-Sachs-Electronics, March-Hugstetten, Germany) with $50 \%$ oxygen; tidal volume $\left(\mathrm{V}_{\mathrm{T}}\right) 7 \mathrm{ml} / \mathrm{kg}$; respiratory rate (RR) 240 minute $^{-1}$; positive end-expiratory pressure (PEEP) $6 \mathrm{cmH}_{2} \mathrm{O}$. A carotid artery catheter was placed for blood pressure monitoring and infusion of $\mathrm{NaCl} 0.9 \%$ containing $100 \mathrm{mmol} / \mathrm{l} \mathrm{HCO}_{3}{ }^{-}(350 \mu \mathrm{l} / \mathrm{h})$. There was no additional fluid support in any conducted experiment. A urinary catheter was inserted. $V_{T}$, $R R$, airway pressure, peripheral oxygen saturation and urine output were monitored (Pulmodyn, Hugo-Sachs-Electronics, March-Hugstetten, Germany; MouseOx, STARR
Life-Sciences, Oakmont, PA, USA). After preparation, a recruitment maneuver was performed (airway pressure $35 \mathrm{cmH}_{2} \mathrm{O}$ for $5 \mathrm{sec}$ ) before respirator settings were adjusted for $6 \mathrm{~h}$ to $\mathrm{V}_{\mathrm{T}} 12 \mathrm{ml} / \mathrm{kg}$, RR 120 minute $^{-1}$, PEEP $2 \mathrm{cmH}_{2} \mathrm{O}$. All mice survived the protocol. At termination of the experiments mice were sacrificed by exsanguination via the carotid catheter. Non-ventilated mice served as controls.

\section{Simvastatin treatment}

Simvastatin (Sigma, Steinheim, Germany) was dissolved in ethanol and diluted with saline. Mice received i.p. injections of $20 \mathrm{mg} / \mathrm{kg}$ simvastatin or solvent $24 \mathrm{~h}$ and $1 \mathrm{~h}$ before the VILI experiment. Non-ventilated mice were treated in according intervals. Simvastatin treatment had no impact on overall cholesterol, HDL and LDL cholesterol in studied mice.

\section{Blood gas analyses}

Blood samples were analyzed for $\mathrm{p}_{\mathrm{a}} \mathrm{O}_{2}, \mathrm{p}_{\mathrm{a}} \mathrm{CO}_{2}$, ph, $\mathrm{HCO}_{3}{ }^{-}, \mathrm{SBE}$, Lactate, $\mathrm{Na}^{+}, \mathrm{K}^{+}, \mathrm{Cl}^{-}, \mathrm{Ca}^{2+}$ by blood gas analyzer (ABL-800, Radiometer, Copenhagen, Denmark). $\mathrm{P} / \mathrm{F}$ ratio was calculated as $\mathrm{p}_{\mathrm{a}} \mathrm{O}_{2} / \mathrm{FiO}_{2}$.

\section{Lung permeability}

Human-Serum-Albumin (HSA; $1 \mathrm{mg}$ ) was injected via carotid artery catheter or tail vein in ventilated or nonventilated mice, respectively, 90 minutes before the experiment termination. Mice were sacrificed and bronchoalveolar lavage (BAL) of the right lung was performed with $2 \times 400 \mu \mathrm{l}$ saline. BAL- and plasma HSAlevels were quantified by ELISA (enzyme-linked immuno sorbent assay) (Bethyl (biomol), Hamburg, Germany). Permeability was assessed by calculating the HSA BAL/ plasma ratio.

\section{Electron microscopy}

Lungs were flushed via the pulmonary artery, cut, immersion-fixed (1.5\% glutaraldehyde, $1.5 \%$ paraformaldehyde in $0.15 \mathrm{M}$ HEPES), rinsed (0.1 mmol/l HEPES, $0.1 \mathrm{mmol} / \mathrm{l}$ cacodylate buffer) and osmicated (1\% osmium tetroxide in $0.1 \mathrm{mmol} / \mathrm{l}$ cacodylate buffer). After rinsing in $0.1 \mathrm{mmol} / \mathrm{l}$ cacodylate buffer and distilled water, specimens were stained in half-saturated aqueous uranylacetate solution (1:1). Samples were dehydrated in ascending acetone concentrations, embedded in epon, cut $(70 \mathrm{~nm})$, stained with lead citrate and uranyl-acetate, and analyzed.

\section{Differential cell count lung}

Lungs were flushed. The left lung was digested in RPMI containing Collagenase and DNAse for $1 \mathrm{~h}$. Leukocytes were extracted by meshing the lung tissue through a cell strainer $(100 \mu \mathrm{m})$ and counted by haemocytometer and 
differentiated by flowcytometry according to their sidescatter/forward-scatter properties and CD45, Gr-1 and F4-80 expression.

\section{Differential cell count blood}

Leukocytes were quantified by flowcytometry using TruCount-Tubes and differentiated according to their sidescatter/forward-scatter properties and CD45 and Gr-1 expression.

\section{Quantification of cytokines}

Cytokines were quantified from total protein of flushed homogenized left lungs and blood samples (BioRad, Hercules, CA, USA).

\section{Measurement of Alanine transaminase levels}

Alanine transaminase (ALT) levels were measured by routine laboratory test at the Institute of Laboratory Medicine and Pathobiochemistry of the Charité Universitätsmedizin Berlin.

\section{Statistic analyses}

Groups were compared using One-Way-ANOVA following Newman-Keuls post test. For comparison of two groups Mann-Whitney U-Test was applied. P-values < 0.05 were considered significant. Data are represented as mean + /- SEM.

\section{Results}

Simvastatin prevented oxygenation failure in VILI

The decline of the peripheral oxygen saturation $\left(\mathrm{SpO}_{2}\right)$ observed in ventilated mice was prevented by Simvastatin treatment (Figure 1a). At the termination of the experiment, blood gas analysis was performed in arterial blood samples. The P/F ratio was higher in simvastatin treated mice (Figure 1b).

\section{Simvastatin reduced VILI-associated pulmonary vascular leakage}

MV induced a marked increase of pulmonary microvascular permeability in mice, indicated by an elevated HSA BAL/plasma ratio. Pulmonary hyperpermeability was decreased by Simvastatin treatment (Figure 2).

\section{Simvastatin attenuated endothelial injury in ventilated mice}

Non-ventilated, untreated or simvastatin treated mice exhibited intact alveolar epithelium and capillary endothelium (Figure 3a-d). Capillary endothelial cells of ventilated and untreated mice were swollen and showed loss of intracellular vesicles and caveolae (Figure $3 \mathrm{e}, \mathrm{f}$ ). In ventilated and simvastatin treated lungs, endothelial cells displayed fewer signs of injury as compared to ventilated and untreated mice. Swelling of endothelial

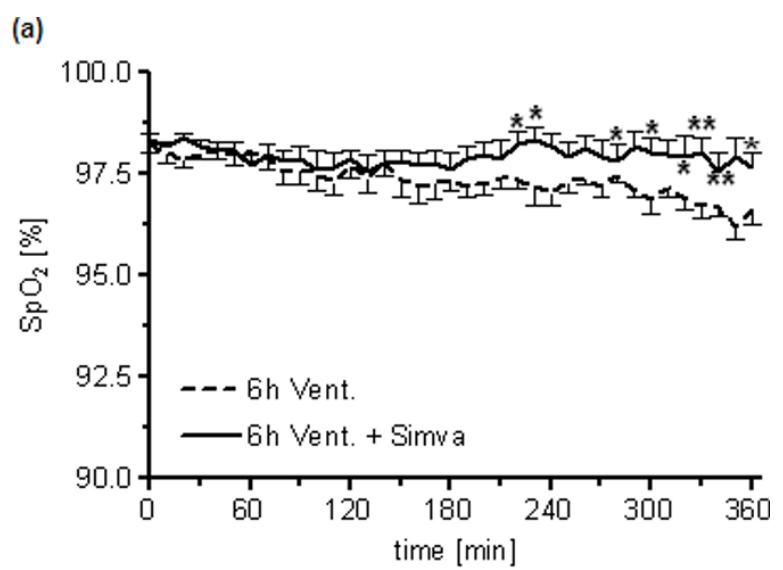

(b)

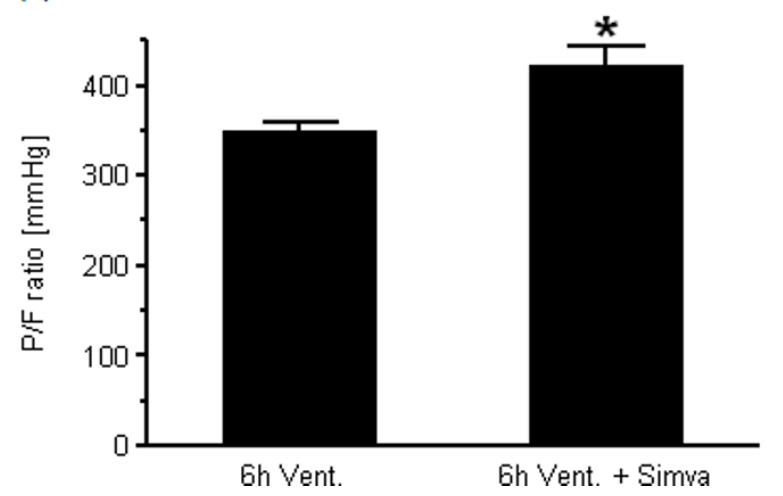

Figure 1 Simvastatin improved oxygenation in VILI. (a) Peripheral Oxygen Saturation $\left(\mathrm{SpO}_{2}\right)$ was monitored continuously and (b) P/F ratio was assessed at the end of the $6 \mathrm{~h}$ ventilation period in simvastatin ( $6 \mathrm{~h}$ Vent. + Simva) or sham ( $6 \mathrm{~h}$ Vent.) treated mice. Simvastatin treatment prevented the decline of $\mathrm{SpO}_{2}$ and improved oxygenation in VILI. (a: 6 h Vent. $N=8 ; 6$ h Vent. + Simva $n=10$; b: 6 h Vent. $N=7 ; 6$ h Vent. + Simva $n=9$; $\left.{ }^{*}<0.05\right)$.

cells occurred only sporadically, and normal distribution of vesicles and caveolae was preserved by simvastatin (Figure 3g, h).

Simvastatin limited the recruitment of PMN and Gr-1 ${ }^{\text {high }}$ monocytes to the lung in VILI

MV evoked PMN and Gr-1 $1^{\text {high }}$ monocyte recruitment to the lung, which was reduced by simvastatin treatment (Figure 4a, b). Further, MV elicited an increase of circulating PMN and monocyte counts, whereas lymphocyte counts were unaltered in the blood (Figure 4c-f). Notably, following simvastatin treatment monocyte counts were increased significantly and PMN counts were increased by trend in blood of ventilated mice (Figure 4c, d).

\section{Simvastatin treatment attenuated VILI-associated} pulmonary cytokine production

MV induced an increase of IL-1 $\beta$, IL-6, IL-12p40, MIP$1 \alpha$, MIP-2 and MCP-1 in the lung tissue. Simvastatin 




Figure 2 Simvastatin reduced VILI-associated lung hyperpermeability. Human serum albumin (HSA; $1 \mathrm{mg}$ ) was injected 90 minutes prior to termination of the experiment. In nonventilated simvastatin (NV + Simva) or sham (NV) treated mice, and in ventilated and simvastatin ( 6 h Vent. + Simva) or sham ( 6 h Vent.) treated mice, HSA levels in plasma and BAL were determined. Simvastatin treatment reduced VILI associated lung

hyperpermeability. (NV $n=6 ; \mathrm{NV}+$ Simva $n=7 ; 6$ h Vent. $N=7 ; 6$ h Vent. + Simva $n=6$; ${ }^{*} P<0.05$, ${ }^{* * *} P<0.001$ ).

treatment attenuated the ventilation-evoked increase of IL-1 $\beta$, IL-12p40 and MIP- $1 \alpha$ in the lung tissue (Figure 5).

\section{Simvastatin treatment attenuated VILI-associated IL-12p40 increase in plasma}

MV evoked an increase of IL-1 $\beta$, IL-6, IL-12p40, MIP$1 \alpha$, MIP-2 and MCP-1 in blood plasma. Simvastatin treatment attenuated the VILI-associated increase of IL12 p40 in the plasma. All other quantified cytokines did not show statistically significant alterations due to simvastatin treatment in ventilated mice (Table 1 ).

Hemodynamics, urine output electrolytes, acid-base homeostasis and markers of hepatic and renal function Continuous monitoring of systemic arterial blood pressure and quantification of electrolytes, parameters of acid-base homeostasis, renal and global hepatic function and urine output at the end of the experiment demonstrated standardization of experimental procedures.

Simvastatin treatment did not alter blood pressure, urine output electrolyte levels or acid-base homeostasis in mechanically ventilated mice. Further simvastatin had no impact on renal function or ALT levels in plasma (Table 2).

\section{Discussion}

Mechanical ventilation may evoke ventilator-induced lung injury even under employment of protective ventilation strategies. Adjuvant pharmacologic approaches to reduce VILI in addition to protective ventilation may further improve morbidity and mortality of ventilated patients. Investigating VILI in a mouse model of $\mathrm{MV}$, the current study for the first time provides experimental evidence that simvastatin treatment may limit VILI in vivo. Simvastatin reduced VILI-associated hyperpermeability, endothelial injury, neutrophil and monocyte recruitment, and inflammation in murine lungs.

Mouse models have been successfully used to investigate pathomechanisms of VILI [18-20]. The currently employed mouse model allowed us to analyze key features of VILI while avoiding detrimental lung injury due to high airway pressures, tidal volumes or respiration rates. Although a $V_{\mathrm{T}}$ of $6 \mathrm{ml} / \mathrm{kg}$ is recommended for lung protective ventilation, we employed a $\mathrm{V}_{\mathrm{T}}$ of $12 \mathrm{ml} /$ $\mathrm{kg}$ which allowed for limitation of respiratory rates in our model, an important independent trigger of VILI in mice [21]. Further lung stress and lung strain, generated by a $\mathrm{V}_{\mathrm{T}}$ of $12 \mathrm{ml} / \mathrm{kg}$ affecting healthy lungs in the current model may apply in ventilated areas of inhomogeneously injured lungs even under lung protective ventilation according to the baby lung concept of the inhomogeneous ARDS lung [22,23]. To further enhance clinical relevance, we prevented hemodynamic instability by fluid support and metabolic acidosis by adequate infusion of sodium bicarbonate. In summary, a mouse model was established for the current study, which evoked moderate lung injury by ventilation for a sixhour period.

Microvascular leakage, a hallmark of VILI evokes lung edema, reduction of lung compliance, surfactant dysfunction, and finally deterioration of pulmonary gas exchange [4]. Statins prevented pulmonary hyperpermeability in ALI evoked by different stimuli, including endotoxin and ischemia/reperfusion [8-10]. Of note, simvastatin treatment also reduced VILI-associated pulmonary hyperpermeability and improved pulmonary gas exchange in the current study.

Different mechanisms of endothelial barrier protection by HMG-CoA reductase inhibitors have been reported, including inhibition of the RhoA/Rho kinase pathway with consecutive reduction of endothelial myosin light chain phosphorylation [24-26], stabilization of endothelial junctions by polymerization of cortical actin [25], as well as downregulation of endothelial caldesmon and upregulation of integrin $\beta 4$ expression in endothelial cells [25]. Although these mechanisms were not evaluated in detail in the current study, they may have been contributing to the observed improvement of barrier function in murine VILI. Notably, an additional way of endothelial cell protection by simvastatin has now been observed by electron microscopy. Simvastatin attenuated VILI-evoked cell swelling and loss of intracellular vesicle 

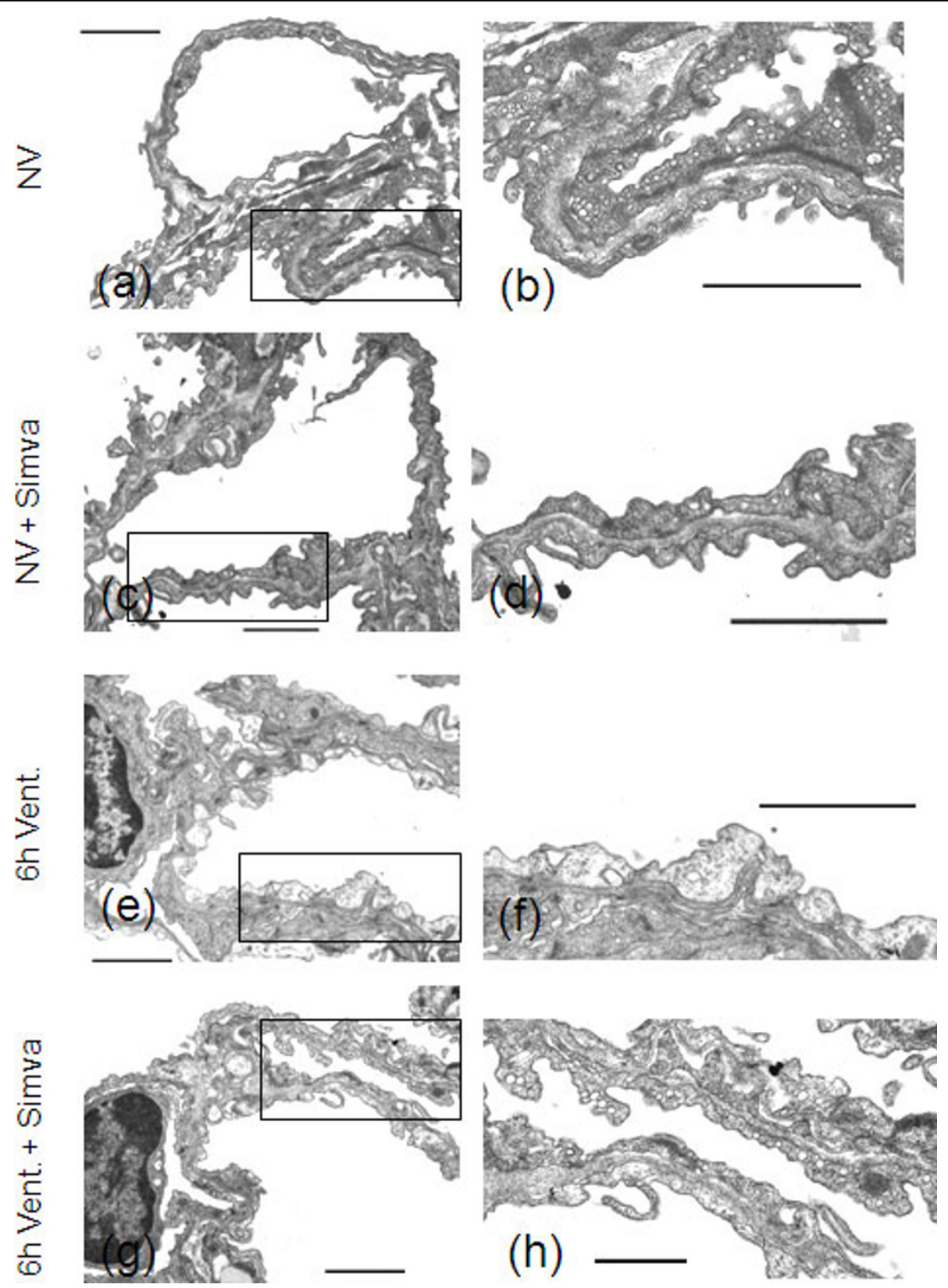

Figure 3 Simvastatin reduced VILI-associated endothelial injury. In lung sections of non ventilated, sham treated mice (NV) (a, b) and nonventilated, simvastatin treated mice (NV + Simva) $(\mathbf{c}, \mathbf{d})$ ), structurally intact capillaries containing numerous caveolae and vesicles in endothelial cells were seen. In lung sections of ventilated, sham treated mice ( $6 \mathrm{~h}$ Vent.) $(\mathbf{e}, \mathbf{f})$, capillaries showed pronounced endothelial cell swelling as well as loss of intracellular vesicles and caveolae. Lungs of ventilated, simvastatin treated mice ( 6 h Vent. + Simva) (g, h) had intact capillaries, and neither signs of endothelial cell swelling, nor reduction of intracellular vesicles was observed. (Representative images out of $n=8$ each group are shown. Bar $2 \mu \mathrm{m})$.

structures in lung endothelium, which are indicators of energy depletion and impaired cell metabolism. Previous in vitro and in vivo studies linked cyclic stretch with apoptosis and necrosis of pulmonary epithelial cells $[27,28]$. In line with the works of Vaneker et al. this study provides ultrastructural in vivo evidence for lung endothelial cell injury following ventilation with moderate tidal volumes [29]. The observed morphologic findings resemble alterations observed in capillary stress failure previously described by West et al. To the best of our knowledge this is the first study showing that a pharmacologic treatment attenuated endothelial injury VILI. This previously undescribed effect of simvastatin treatment suggests a so far unknown beneficial effect of 

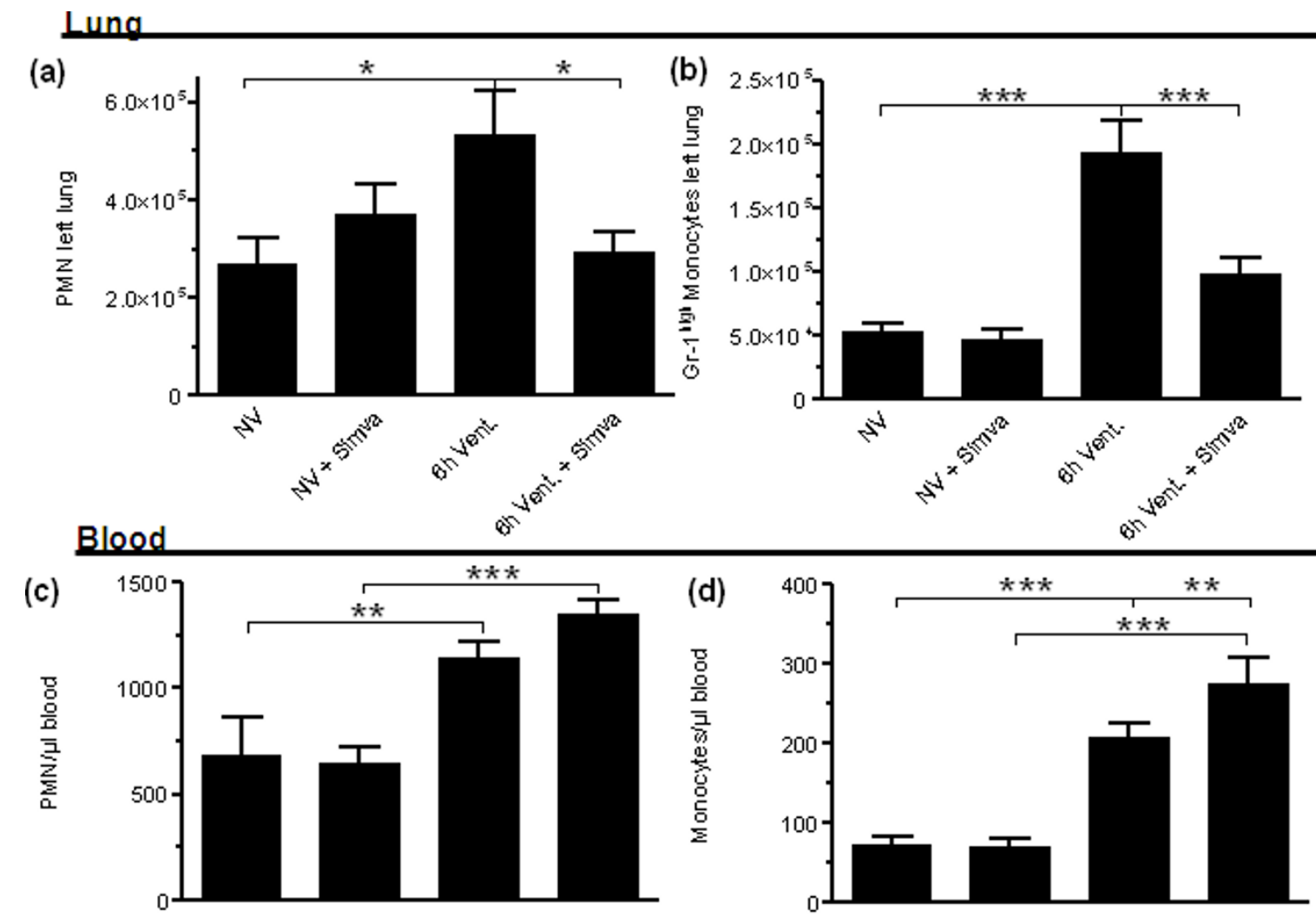



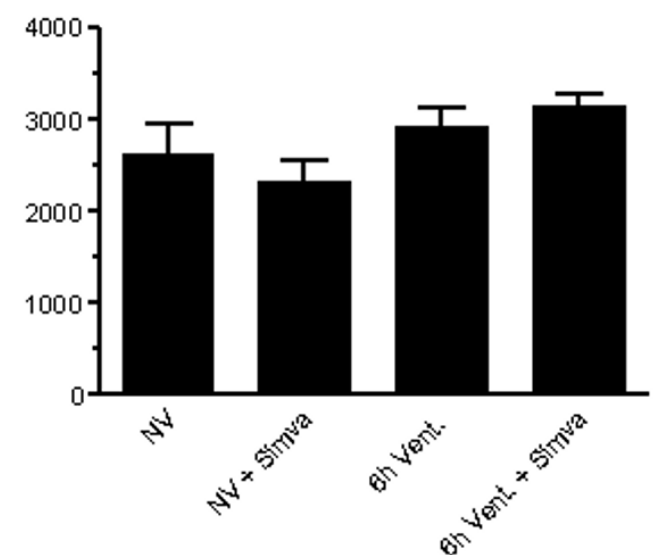

(f)

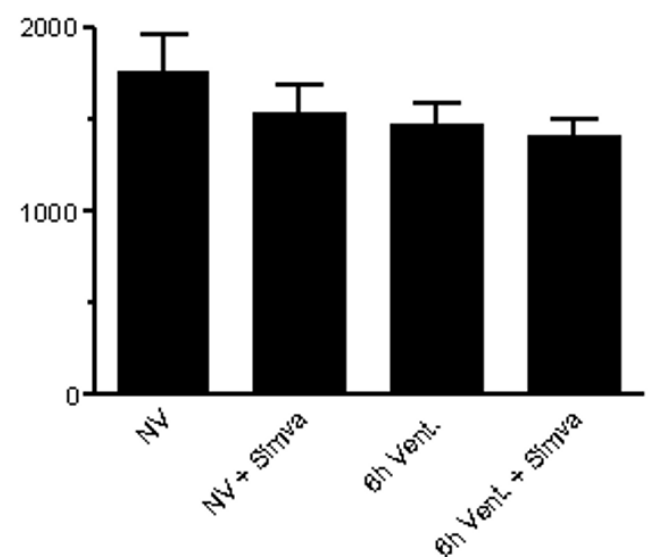

Figure 4 Simvastatin treatment limited VILI-associated pulmonary leukocyte infiltration. After $6 \mathrm{~h}$ mechanical ventilation (MV) of simvastatin ( $6 \mathrm{~h}$ Vent + Simva) or sham treated mice ( $6 \mathrm{~h}$ Vent.) and in non-ventilated sham (NV) or simvastatin (NV + Simva) treated mice, leukocytes isolated from whole left lung tissue and from blood were differentiated by flow cytometry. MV increased pulmonary PMN (a) and GR$1^{\text {high }}$ monocytes (b). Simvastatin reduced PMN and monocyte counts in the lungs of ventilated mice. MV also increased circulating blood neutrophils (c) and Gr-1 ${ }^{\text {high }}$ monocytes (d), whereas leukocyte (e) and lymphocyte (f) counts were not significantly altered by MV (F). PMN and $\mathrm{Gr}-\mathrm{-}^{\text {high }}$ monocyte counts were higher in Simvastatin treated, ventilated mice ( $6 \mathrm{~h}$ Vent. + Simva), as compared to sham treated, ventilated mice (6 h Vent.). (a-b: NV $n=6 ;$ NV + Simva $n=7 ; 6$ h Vent. $N=7 ; 6$ h Vent. + Simva $n=6$. c-d: NV $n=9 ; N V+$ Simva $n=9 ; 6$ h Vent. $N=8 ; 6$ h Vent. + Simva $n=8$; ${ }^{*} P<0.05$; ${ }^{* *} P<0.01$, ${ }^{* *} P<0.001$ ).

HMG-CoA reductase inhibitors, which may be further examined in future studies.

In VILI, PMN and Gr-1 ${ }^{\text {high }}$ monocytes infiltrate the lungs and have been identified as major effector cells for the development of tissue damage [30-32]. Reportedly, simvastatin inhibited tissue leukocyte infiltration in ALI both in animal experiments and in humans $[8,9,12]$. Leukocyte rolling, adhesion and transmigration were attenuated by simvastatin, at least partly by reduction of adhesion molecules including CEACAM-1, VCAM-1 


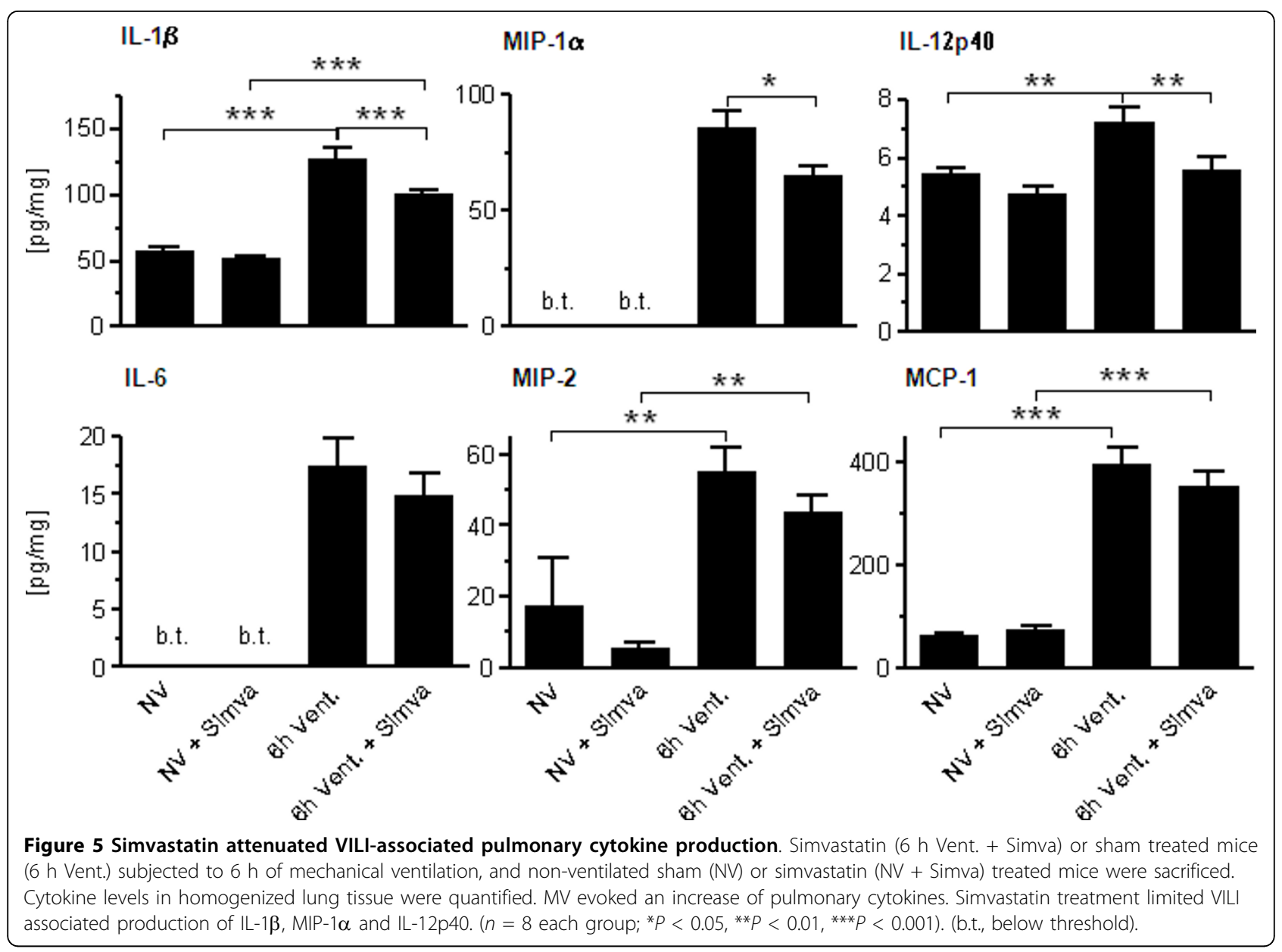

and PCAM-1 [33-36]. In line, the significant recruitment of PMN and Gr-1 ${ }^{\text {high }}$ monocytes in murine VILI was diminished by simvastatin in the current study. Moreover, an MV-induced increase of circulating PMN and Gr-1 $1^{\text {high }}$ monocytes in the blood was even more pronounced in simvastatin-treated mice. This observation may suggest that simvastatin-evoked inhibition of endothelial leukocyte recruitment contributed to reduced pulmonary and concomitantly increased blood counts of PMN and Gr-1 ${ }^{\text {high }}$ monocytes.

Simvastatin reduced production and liberation of various cytokines in animal models of ALI, sepsis and asthma as well as in humans following LPS-inhalation $[9,11,12,37-40]$. In the current study, VILI-associated pulmonary production of IL-1 $\beta$, MIP- $1 \alpha$ and IL-12p40 was reduced by simvastatin treatment. Thus, alteration

Table 1 Simvastatin treatment reduced IL-12p40 levels in plasma

\begin{tabular}{|c|c|c|c|c|c|c|c|c|}
\hline & \multicolumn{2}{|c|}{ NV } & \multicolumn{2}{|c|}{ NV + Simva } & \multicolumn{2}{|c|}{$6 \mathrm{~h}$ Vent. } & \multicolumn{2}{|c|}{6 h Vent. + Simva } \\
\hline & mean $(\mathrm{pg} / \mu \mathrm{l})$ & SD & mean $(\mathrm{pg} / \mu \mathrm{l})$ & SD & mean $(\mathrm{pg} / \mu \mathrm{l})$ & SD & mean $(\mathrm{pg} / \mu \mathrm{l})$ & SD \\
\hline IL-1 $\beta$ & 445.30 & 100.70 & 505.30 & 52.19 & $763.2 * * *$ & 95.38 & 738.8 \#\#\# & 100.40 \\
\hline IL-6 & 57.58 & 62.99 & 133.40 & 90.38 & $915.3^{* * *}$ & 459.00 & 993.9 \#\#\# & 364.60 \\
\hline IL-12p40 & 462.10 & 99.32 & 593.10 & 128.60 & $2,352 * * *$ & 783.40 & 1,785 \#\#\#, ${ }^{a}$ & 372.50 \\
\hline MIP-1 $\alpha$ & 307.20 & 149.10 & 386.50 & 78.94 & $918.6 * * *$ & 318.60 & 900.8 \#\#\# & 128.20 \\
\hline MIP-2 & 15.28 & 35.02 & 10.03 & 9.42 & $95.32^{* *}$ & 49.21 & $67.25 \#$ & 23.73 \\
\hline MCP-1 & 99.84 & 17.33 & 153.50 & 29.41 & $758.9 *$ & 404.90 & 559.70 & 133.30 \\
\hline
\end{tabular}

Cytokine levels were assessed in blood plasma after $6 \mathrm{~h}$ mechanical ventilation (MV) of simvastatin ( $6 \mathrm{~h}$ Vent + Simva) or sham treated mice (6 $\mathrm{h}$ Vent.) and in plasma of non-ventilated simvastatin (NV + Simva) or sham (NV) treated mice. MV induced a systemic inflammatory response indicated by elevated cytokine levels in blood. Simvastatin treatment reduced IL-12p40 levels in plasma significantly. The levels of IL-1 $\beta$, MIP-1 $\alpha$, IL-6, MIP-2 and MCP-1 in VILI did not show statistically significant alterations due to simvastatin treatment. $\left(n=8\right.$ each group; ${ }^{*} P<0.05$, ${ }^{* *} P<0.01, * * * P<0.001$ vs. NV; \# $P<0.05$, \#\#\# $P<0.001$ vs. $\mathrm{NV}+$ Simva; $^{\mathrm{a}} P<0.05$ vs. $6 \mathrm{~h}$ Vent.). 
Table 2 Hemodynamics, electrolytes, respiratory parameters lactate, ALT and Cystatin C levels and urine output of mechanically ventilated mice

\begin{tabular}{|c|c|c|c|c|}
\hline & \multicolumn{2}{|c|}{6 h Vent. } & \multicolumn{2}{|c|}{6 h Vent. + Simva } \\
\hline & mean & SD & mean & SD \\
\hline $\mathrm{Na}^{+}(\mathrm{mmol} / \mathrm{l})$ & 159 & 5 & 159 & 4 \\
\hline $\mathrm{K}^{+}(\mathrm{mmol} / \mathrm{l})$ & 4.7 & 0.5 & 4.7 & 0.4 \\
\hline $\mathrm{Cl}^{-}(\mathrm{mmol} / \mathrm{l})$ & 124 & 4 & 125 & 4 \\
\hline $\mathrm{Ca}^{2+}(\mathrm{mmol} / \mathrm{l})$ & 1.29 & 0.06 & 1.30 & 0.05 \\
\hline ph & 7.45 & 0.08 & 7.51 & 0.08 \\
\hline $\mathrm{p}_{\mathrm{a}} \mathrm{CO}_{2}(\mathrm{mmHg})$ & 42.2 & 4.8 & 34.5 & 10.0 \\
\hline SBE (mmol/l) & 3.0 & 2.1 & 3.5 & 1.7 \\
\hline $\mathrm{HCO}_{3}^{-}(\mathrm{mmol} / \mathrm{l})$ & 26.7 & 2.6 & 26.6 & 2.7 \\
\hline Lactate $(\mathrm{mmol} / \mathrm{l})$ & 1.5 & 0.4 & 1.6 & 0.3 \\
\hline ALT (U/I) & 30 & 12 & 21 & 4 \\
\hline Cystatin C (ng/ml) & 443 & 64 & 479 & 65 \\
\hline MAP $0 \mathrm{~h}(\mathrm{mmHg})$ & 91 & 7 & 87 & 10 \\
\hline MAP $1 \mathrm{~h}(\mathrm{mmHg})$ & 74 & 7 & 72 & 7 \\
\hline MAP $2 \mathrm{~h}(\mathrm{mmHg})$ & 68 & 5 & 70 & 6 \\
\hline MAP $3 \mathrm{~h}(\mathrm{mmHg})$ & 70 & 6 & 70 & 7 \\
\hline MAP $4 \mathrm{~h}(\mathrm{mmHg})$ & 68 & 5 & 69 & 7 \\
\hline MAP $5 \mathrm{~h}(\mathrm{mmHg})$ & 69 & 6 & 67 & 7 \\
\hline MAP $6 \mathrm{~h}(\mathrm{mmHg})$ & 73 & 8 & 72 & 10 \\
\hline Urine Output $6 \mathrm{~h}(\mu \mathrm{l})$ & 908 & 294 & 669 & 207 \\
\hline
\end{tabular}

of chemotaxis may have been contributing to the limitation of PMN and Gr-1 $1^{\text {high }}$ monocyte influx into the lungs in this study. Particularly IL-1 $\beta$ may be a key mediator in VILI, as IL- $1 \beta$ blockade as well as IL-1 $\beta$ deficiency resulted in reduced pulmonary PMN recruitment and hyperpermeability in animal models of VILI [41]. Therefore, dampening of pulmonary IL- $1 \beta$ production by simvastatin may have been adding to the observed attenuation of microvascular leakage, pulmonary leukocyte recruitment and endothelial cell injury.

Although increasing evidence derived from experimental and observational studies suggests beneficial effects of simvastatin in ALI as well as in pneumonia [8-11,14,16,42], a retrospective study analyzing an ALI patient cohort did not find an outcome improvement by conventional statin treatment [43]. Of note, statin doses of $5 \mathrm{mg} / \mathrm{kg} / \mathrm{d}$ did not improve experimental ALI [8], whereas higher doses of 10 to $20 \mathrm{mg} / \mathrm{kg} / \mathrm{d}$ evoked protective effects. Further, previous studies suggested a delay of at least $6 \mathrm{~h}$ for the development of barrier-protective effects by simvastatin $[24,25]$. Thus, mice were pretreated with $20 \mathrm{mg} / \mathrm{kg} / \mathrm{d}$ simvastatin commencing $24 \mathrm{~h}$ before the onset of ventilation in the current study. Although mandatory for this experimental approach, simvastatin pre-treatment does not match the clinical scenario. However, animal studies are limited to hours while ARDS patients often are ventilated for days or even weeks. Taking this long time course in account we believe that simvastatin may deliver its beneficial effects over time when it is given with the initation of MV. Notably, an upcoming randomized controlled NHLBI sponsored trial is going to investigate statin therapy in ALI (NCT00979121). As patients included in this trial will presumably receive respirator therapy, the effects of statins on VILI observed in the current experimental study may possibly contribute to the outcome of the treatment arm.

\section{Conclusions}

This study shows, for the first time, that high-dose simvastatin markedly reduced VILI-associated microvascular leakage and improved pulmonary gas exchange in mechanically ventilated mice. Simvastatin prevented recruitment of PMN and $\mathrm{Gr}-1^{\text {high }}$ monocytes to the lung, limited pulmonary cytokine production and attenuated endothelial injury in VILI. The data suggest that high-dose simvastatin offers a promising perspective to prevent VILI in addition to lung protective ventilation.

\section{Key messages}

- Simvastatin improved microvascular leakage and improved oxygenation in VILI.

- Simvastatin limited pulmonary hyperinflammation in VILI.

- Simvastatin protected against VILI induced pulmonary endothelial injury.

- Simvastatin offers a promising perspective to limit VILI in addition to lung protective ventilation.

\section{Abbreviations}

ALI: acute lung injury; ALT: Alanine transaminase; BAL: bronchoalveolar lavage; ELISA: enzyme-linked immuno sorbent assay; HMG COA: 3-hydroxy-3methylglutaryl coenzyme A; HAS: human serum albumin; LPS:

lipopolysacharide; MV: mechanical ventilation; PEEP: positive end-expiratory pressure; VILI: ventilator-induced lung injury; $V_{T}$ : tidal volume pressure.

\section{Acknowledgements}

We thank A. Santel for thoughtful discussion and useful advice and Andrea Schoenknecht for technical support.

This study was supported in part by grants from the German Research Foundation to MW (OP 86/7-1) and SH (HI-789/6-1), and the German Federal Ministry of Education and Research to HCM, NS and SR (Pneumonia Research Network on Genetic Resistance and Susceptibility for the Evolution of Severe Sepsis PROGRESS)

\section{Author details}

'Department of Infectious Diseases and Pulmonary Medicine, Charité Universitätsmedizin Berlin, Charitéplatz 1, 10117 Berlin, Germany. ${ }^{2}$ Institute for Anatomy and Cell Biology, Saarland University Faculty of Medicine, Kirrberger Straße, Building 61, 66421 Homburg Saar, Germany. ${ }^{3}$ Institute for Functional and Applied Anatomy, Medical School of Hannover, CarlNeuberg-Str. 1, 30625 Hannover, Germany. ${ }^{4}$ BMBF-Forsys Junior Research Group "Systems Biology of Lung Inflammation (FORSYS Lung)", Charitéplatz 
1, 10117 Berlin, Germany. ${ }^{5}$ Department of Nephrology, Charité Universitätsmedizin Berlin, Charitéplatz 1, 10117 Berlin, Germany. ${ }^{6}$ Institute of Pathology, Charité - Universitätsmedizin Berlin, Charitéplatz 1, 10117 Berlin, Germany.

\section{Authors' contributions}

HCM designed, coordinated and supervised all experiments, analysed the data and drafted the manuscript. KH and BG carried out the animal experiments and performed flow cytometry experiments. SR contributed to the design of the experiments and drafted the manuscript. $T$ T and AS performed electron microscopy and were responsible for image analysis. BS and SH carried out multiplex array experiments while HP performed cystatin $\mathrm{C}$ analysis and NS participated in drafting the manuscript. MW participated in the study design and drafted the manuscript.

\section{Competing interests}

The authors declare that they have no competing interests.

Received: 25 March 2010 Revised: 13 May 2010 Accepted: 30 July 2010 Published: 30 July 2010

\section{References}

1. Esteban A, Anzueto A, Frutos F, Alia I, Brochard L, Stewart TE, Benito S, Epstein SK, Apezteguia C, Nightingale P, Arroliga AC, Tobin MJ: Characteristics and outcomes in adult patients receiving mechanical ventilation: a 28-day international study. JAMA 2002, 287:345-355.

2. Dhanireddy S, Altemeier WA, Matute-Bello G, O'Mahony DS, Glenny RW, Martin TR, Liles WC: Mechanical ventilation induces inflammation, lung injury, and extra-pulmonary organ dysfunction in experimental pneumonia. Lab Invest 2006, 86:790-799.

3. O'Mahony DS, Liles WC, Altemeier WA, Dhanireddy S, Frevert CW, Liggitt D, Martin TR, Matute-Bello G: Mechanical ventilation interacts with endotoxemia to induce extrapulmonary organ dysfunction. Crit Care 2006, 10:R136

4. Verbrugge SJ, Lachmann B, Kesecioglu J: Lung protective ventilatory strategies in acute lung injury and acute respiratory distress syndrome: from experimental findings to clinical application. Clin Physiol Funct Imaging 2007, 27:67-90.

5. Ventilation with lower tidal volumes as compared with traditional tidal volumes for acute lung injury and the acute respiratory distress syndrome. The Acute Respiratory Distress Syndrome Network. N Engl J Med 2000, 342:1301-1308.

6. Amato MB, Barbas CS, Medeiros DM, Magaldi RB, Schettino GP, LorenziFilho G, Kairalla RA, Deheinzelin D, Munoz C, Oliveira R, Takagaki TY, Carvalho CR: Effect of a protective-ventilation strategy on mortality in the acute respiratory distress syndrome. N Engl J Med 1998, 338:347-354.

7. Wolthuis EK, Vlaar AP, Choi G, Roelofs JJ, Juffermans NP, Schultz MJ: Mechanical ventilation using non-injurious ventilation settings causes lung injury in the absence of pre-existing lung injury in healthy mice. Crit Care 2009, 13:R1.

8. Jacobson JR, Barnard JW, Grigoryev DN, Ma SF, Tuder RM, Garcia JGN: Simvastatin attenuates vascular leak and inflammation in murine inflammatory lung injury. Am J Physiol Lung Cell Mol Physiol 2005, 288: L1026-L1032.

9. Naidu BV, Woolley SM, Farivar AS, Thomas R, Fraga C, Mulligan MS: Simvastatin ameliorates injury in an experimental model of lung ischemia-reperfusion. Journal of Thoracic and Cardiovascular Surgery 2003, 126:482-489.

10. Pirat A, Zeyneloglu P, Aldemir D, Yucel M, Ozen O, Candan S, Arslan G: Pretreatment with simvastatin reduces lung injury related to intestinal ischemia-reperfusion in rats. Anesth Analg 2006, 102:225-232.

11. Shao H, Shen $Y$, Liu H, Dong G, Qiang J, Jing H: Simvastatin suppresse lung inflammatory response in a rat cardiopulmonary bypass model. The Annals of Thoracic Surgery 2007, 84:2011-2018.

12. Shyamsundar M, McKeown ST, O'Kane CM, Craig TR, Brown V, Thickett DR, Matthay MA, Taggart CC, Backman JT, Elborn JS, McAuley DF: Simvastatin decreases lipopolysaccharide induced pulmonary inflammation in healthy volunteers. Am J Respir Crit Care Med 2009, 179:1107-1114.

13. Martin CP, Talbert RL, Burgess DS, Peters Jl: Effectiveness of statins in reducing the rate of severe sepsis: a retrospective evaluation. Pharmacotherapy 2007, 27:20-26.
14. Mortensen EM, Pugh MJ, Copeland LA, Restrepo MI, Cornell JE, Anzueto A, Pugh JA: Impact of statins and angiotensin-converting enzyme inhibitors on mortality of subjects hospitalised with pneumonia. Eur Respir J 2008, 31:611-617.

15. Schmidt H, Hennen R, Keller A, Russ M, Muller-Werdan U, Werdan K, Buerke M: Association of statin therapy and increased survival in patients with multiple organ dysfunction syndrome. Intensive Care Med 2006, 32:1248-1251.

16. Thomsen RW, Riis A, Kornum JB, Christensen S, Johnsen SP, Sorensen HT: Preadmission use of statins and outcomes after hospitalization with pneumonia: population-based cohort study of 29,900 patients. Arch Intern Med 2008, 168:2081-2087.

17. Ranieri VM, Suter PM, Tortorella C, De Tullio R, Dayer JM, Brienza A, Bruno F, Slutsky AS: Effect of mechanical ventilation on inflammatory mediators in patients with acute respiratory distress syndrome: a randomized controlled trial. JAMA 1999, 282:54-61.

18. Hoetzel A, Dolinay T, Vallbracht S, Zhang Y, Kim HP, Ifedigbo E, Alber S, Kaynar AM, Schmidt R, Ryter SW, Choi AM: Carbon monoxide protects against ventilator-induced lung injury via PPAR-gamma and inhibition of Egr-1. Am J Respir Crit Care Med 2008, 177:1223-1232.

19. Matute-Bello G, Frevert CW, Martin TR: Animal models of acute lung injury. Am J Physiol Lung Cell Mol Physiol 2008, 295:L379-L399.

20. Papaiahgari S, Yerrapureddy A, Reddy SR, Reddy NM, Dodd O, Crow MT, Grigoryev DN, Barnes K, Tuder RM, Yamamoto M, Kensler TW, Biswal S, Mitzner W, Hassoun PM, Reddy SP: Genetic and pharmacologic evidence links oxidative stress to ventilator-induced lung injury in mice. Am J Respir Crit Care Med 2007, 176:1222-1235.

21. Vaporidi K, Voloudakis G, Priniannakis G, Kondili E, Koutsopoulos A, Tsatsanis C, Georgopoulos D: Effects of respiratory rate on ventilatorinduced lung injury at a constant $\mathrm{PaCO} 2$ in a mouse model of normal lung. Crit Care Med 2008, 36:1277-1283.

22. Chiumello D, Carlesso E, Cadringher P, Caironi P, Valenza F, Polli F, Tallarini F, Cozzi P, Cressoni M, Colombo A, Marini JJ, Gattinoni L: Lung stress and strain during mechanical ventilation for acute respiratory distress syndrome. Am J Respir Crit Care Med 2008, 178:346-355.

23. Gattinoni L, Pesenti A: The concept of "baby lung". Intensive Care Med 2005, 31:776-784.

24. Chen W, Pendyala S, Natarajan V, Garcia JGN, Jacobson JR: Endothelial cell barrier protection by simvastatin: GTPase regulation and NADPH oxidase inhibition. Am J Physiol Lung Cell Mol Physiol 2008, 295:L575-L583.

25. Jacobson JR, Dudek SM, Birukov KG, Ye SQ, Grigoryev DN, Girgis RE, Garcia JGN: Cytoskeletal activation and altered gene expression in endothelial barrier regulation by simvastatin. Am J Respir Cell Mol Biol 2004, 30:662-670.

26. Zeng L, Xu H, Chew TL, Eng E, Sadeghi MM, Adler S, Kanwar YS, Danesh FR HMG CoA reductase inhibition modulates VEGF-induced endothelial cell hyperpermeability by preventing RhoA activation and myosin regulatory light chain phosphorylation. FASEB J 2005, 19:1845-1847.

27. Hammerschmidt S, Kuhn H, Grasenack T, Gessner C, Wirtz H: Apoptosis and necrosis induced by cyclic mechanical stretching in alveolar type II cells. Am J Respir Cell Mol Biol 2004, 30:396-402.

28. Imai Y, Parodo J, Kajikawa O, de Perrot M, Fischer S, Edwards V, Cutz E, Liu M, Keshavjee S, Martin TR, Marshall JC, Ranieri VM, Slutsky AS: Injurious mechanical ventilation and end-organ epithelial cell apoptosis and organ dysfunction in an experimental model of acute respiratory distress syndrome. JAMA 2003, 289:2104-2112.

29. Vaneker M, Halbertsma FJ, van Egmond J, Netea MG, Dijkman HB, Snijdelaar DG, Joosten LA, van der Hoeven JG, Scheffer GJ: Mechanical ventilation in healthy mice induces reversible pulmonary and systemic cytokine elevation with preserved alveolar integrity: an in vivo model using clinical relevant ventilation settings. Anesthesiology 2007, 107:419-426.

30. Wilson MR, O'Dea KP, Zhang D, Shearman AD, van Rooijen N, Takata M: Role of lung-marginated monocytes in an in vivo mouse model of ventilator-induced lung injury. Am J Respir Crit Care Med 2009, 179:914-922.

31. Karzai W, Cui X, Heinicke N, Niemann C, Gerstenberger EP, Correa R, Banks S, Mehlhorn B, Bloos F, Reinhart K, Eichacker PQ: Neutrophil stimulation with granulocyte colony-stimulating factor worsens ventilator-induced lung injury and mortality in rats 1 . Anesthesiology 2005, 103:996-1005. 
32. Kawano T, Mori S, Cybulsky M, Burger R, Ballin A, Cutz E, Bryan AC: Effect of granulocyte depletion in a ventilated surfactant-depleted lung. J Appl Physiol 1987, 62:27-33

33. Lin Y, Ye S, Chen Y, Li X, Yang Gw, Fan A, Wang Y: The effect of simvastatin on the serum monocyte chemoattractant protein-1 and intracellular adhesion molecule-1 levels in diabetic rats. Journal of Diabetes and its Complications 2009, 23:214-218.

34. Pruefer D, Makowski J, Schnell M, Buerke U, Dahm M, Oelert H, Sibelius U, Grandel U, Grimminger F, Seeger W, Meyer J, Darius H, Buerke M: Simvastatin inhibits inflammatory properties of Staphylococcus aureus alpha-toxin. Circulation 2002, 106:2104-2110.

35. Wei H, Fang L, Song J, Chatterjee S: Statin-inhibited endothelial permeability could be associated with its effect on PECAM-1 in endothelial cells. FEBS Lett 2005, 579:1272-1278.

36. Zapolska-Downar D, Siennicka A, Kaczmarczyk M, Kolodziej B, Naruszewicz M: Simvastatin modulates TNF[alpha]-induced adhesion molecules expression in human endothelial cells. Life Sciences 2004, 75:1287-1302.

37. Kim DY, Ryu SY, Lim JE, Lee YS, Ro JY: Anti-inflammatory mechanism of simvastatin in mouse allergic asthma model. European Journal of Pharmacology 2007, 557:76-86.

38. McKay A, Leung BP, McInnes IB, Thomson NC, Liew FY: A novel antiinflammatory role of simvastatin in a murine model of allergic asthma1. J Immunol 2004, 172:2903-2908.

39. Souza Neto JL, Araujo FI, Rego AC, Dominici VA, Azevedo IM, Egito ES, Brandao-Neto J, Medeiros AC: Effects of simvastatin in abdominal sepsis in rats. Acta Cir Bras 2006, 21:8-12.

40. Yasuda H, Yuen PST, Hu X, Zhou H, Star RA: Simvastatin improves sepsisinduced mortality and acute kidney injury via renal vascular effects. Kidney Int 2006, 69:1535-1542.

41. Frank JA, Pittet JF, Wray C, Matthay MA: Protection from experimental ventilator-induced acute lung injury by IL-1 receptor blockade. Thorax 2008, 63:147-153.

42. Nakagawa $H$, Tsunooka N, Yamamoto $Y$, Yoshida M, Nakata T, Kawachi K: Pitavastatin prevents intestinal ischemia/reperfusion-induced bacterial translocation and lung injury in atherosclerotic rats with hypoadiponectinemia. Surgery 2009, 145:542-549.

43. Kor DJ, Iscimen R, Yilmaz M, Brown MJ, Brown DR, Gajic O: Statin administration did not influence the progression of lung injury or associated organ failures in a cohort of patients with acute lung injury. Intensive Care Med 2009, 35:1039-1046.

doi:10.1186/cc9209

Cite this article as: Müller et al: Simvastatin attenuates ventilatorinduced lung injury in mice. Critical Care 2010 14:R143.

\section{Submit your next manuscript to BioMed Central and take full advantage of:}

- Convenient online submission

- Thorough peer review

- No space constraints or color figure charges

- Immediate publication on acceptance

- Inclusion in PubMed, CAS, Scopus and Google Scholar

- Research which is freely available for redistribution

Submit your manuscript at www.biomedcentral.com/submit
Biomed Central 